\title{
REVIEWS
}

DE GLACIOLOGISKA UNDERSÖKNINGARNA I KEBNEKAJSE 1946-49. (Glaciological studies in Kebnekajse).

By Hans $W$ :son Ahrmann. Lund; Sweden: Geografisk Arsbok, No. 77 (1950) pp. 106-127. (In Swedish with a summary in English).

In 1945, when Professor Ahlmann resumed his researches on the glaciers around the Norwegian Sea, he decided to undertake a systematic study of relatively continental glaciers. After a reconnaissance by his assistant, Valter Schytt, he chose the Storglaciär and the Rabots Gläciar in the Kebnekajsemassiv $\left(67^{\circ} 50 \mathrm{~N}\right.$.) of Swedish Lapland. The main objective was to study the effect of the modern climatic change on the volume of the glaciers. The field staff was headed by Schytt.

The accumulation of snow was determined with the aid of bamboo stakes, pits, and seismic soundings; the specific gravity of the snow was determined; and the volume of the water was calculated. Since meltwater trickling down into the snow refreezes upon reaching the cold lower strata, and since below the névé limit some meltwater forms superimposed ice, the ablation, or loss by melting and evaporation, is not easily determined.
Schytt and his associates therefore dug pits down to the autumn surface of the previous year to determine the water content of the snow at various levels and the thickness of the superimposed ice.

By comparison of old maps with recent maps and photographs the average annual decrease of the Storglaciär during the period 1922-46 was calculated to have been 2.6 million cubic metres of water. In 1946-7 the loss was 6.4 million cubic metres, in 1947-8 the budget was balanced, and in 1948-9 there was a surplus of about 2.8 million cubic metres of water.

The excessive ablation, which ended in 1947, was evidently connected with the climatic change which has gone on for about a hundred years; but whether the large snow surplus in 1948-9 was a temporary reversal of the preceding long trend or is the beginning of an opposite climatic trend, only the future can tell.

Ahlmann himself devoted the summers of 1948 and 1949 to the study of the crystal structure of glacier ice. E. Bergström mapped the numerous glaciers in the Kebnekajsemassiv, their moraines, and the adjacent vegetation belts. In addition meteorological observations were made, and instruments were tested.

ERnst Antevs

\section{NORTHERN NEWS}

\section{Aircraft accident at Alert}

On 31 July 1950 an R.C.A.F. Lancaster aircraft crashed at the weather station Alert, near Cape Sheridan, north Ellesmere Island, killing Colonel C. J. Hubbard of the United States Weather Bureau, Dr. D. W. Kirk of the Geographical Branch, Department of Mines and Technical Surveys, and the seven members of the crew. The crew were: W/C D. French; F/O T. D. Martin; F/L L. M. Maclean; F/O J. R. Dube; F/L J. F. Swinton; F/O J. E. McCutch-

${ }_{1}^{1}$ Reprinted in the main from the Arctic Circular, Vol. 3, No. 4 (1950) pp. 46-7. eon; and LAC R. L. Sprange.

The Lancaster was one of two, based at Greenwood, N.S., used for longrange ice reconnaissance by the supply mission to the joint Canadian/United States northern weather stations. The aircraft was dropping supplies to the weather station when a parachute caught in the tail assembly causing the aircraft to crash. All the occupants were killed immediately and were buried at Alert. It had been intended that their bodies should be brought out, but a Canso which was sent north for this task hit some ice off the station and was dam- 